\title{
CCR6 is not necessary for functional effects of human CCL18 in a mouse model
}

Irina G Luzina ${ }^{1,2}$ and Sergei P Atamas ${ }^{1,2^{*}}$

\begin{abstract}
CCL18, a chemokine with no known receptor, has been implicated in several fibrotic pulmonary diseases associated with T-lymphocyte infiltration. It has been hypothesized that CCL18 may act through CCR6. Gene delivery of human CCL18 to the lungs of wild-type mice induced pulmonary infiltration of T-lymphocytes, less than $5 \%$ of which expressed CCR6. In the lungs of CCR6-deficient mice, CCL18-driven infiltration of T-lymphocytes was attenuated but not fully abrogated. It was concluded that CCR6 is not necessary for CCL18-induced changes in mice in vivo and that CCR6 is not the main functional receptor for CCL18 in this model.
\end{abstract}

Keywords: CCL18, CCR6, fibrosis, inflammation, T-lymphocytes

\section{Correspondence}

CC chemokine ligand 18 (CCL18, also termed MIP-4, PARC, AMAC-1, DC-CK-1 and SCYA18) is a chemokine that has been implicated in several fibrotic pulmonary diseases associated with T-lymphocyte infiltration [1-5]. This cytokine has no known receptor and is present in humans but not in mice [6-9], although human CCL18 is fully functionally active in mice in vivo, causing chemotaxis of T-lymphocytes [3-5,9]. These observations suggest that although CCL18 was lost in mice after evolutionary separation from human ancestors, the receptor for it has been preserved in both mice and humans. Identification of a functional CCL18 receptor would allow for development of therapies targeting CCL18-driven lymphocytic inflammation and fibrosis. However, major efforts of numerous laboratories for more than a decade failed to identify a CCL18 receptor. At this point, excluding CCL18 receptor candidates becomes important for narrowing the spectrum of potential cell surface molecules that may band CCL18 and mediate its effects, and thus for avoiding duplicating the efforts of various investigators.

It has been recently suggested [10] that CC chemokine receptor 6 (CCR6) may be a functional receptor for CCL18. CCR6 is known as the receptor for a different

\footnotetext{
* Correspondence: satamas@umaryland.edu

'Department of Medicine, University of Maryland School of Medicine, Baltimore, MD 21201, USA

Full list of author information is available at the end of the article
}

chemokine, CCL20 (also termed LARC or MIP-3 $\alpha$ ), and human CCL20 is biologically active in mice in vivo and on mouse cells in culture [11,12]. Therefore, we hypothesized that if CCR6 is a receptor for CCL18, the effects of human CCL18 in mice [3-5,9] may be mediated by mouse CCR6.

\section{Findings}

To address this hypothesis, two types of experiments have been performed. In the first series of experiments, wild-type C57Bl/6 mice (The Jackson Laboratory, Bar Harbor, ME, USA) received intratracheal instillations of a replication-deficient recombinant adenoviral construct encoding human CCL18 (AdV-CCL18), exactly as described previously [3-5]. Control mice received similar amounts of AdV-NULL, which does not encode a cytokine. Three animals per group were analyzed in two independent experiments, with similar results. Fourteen days after instillations, bronchoalveolar lavage (BAL) was analyzed by flow cytometry, revealing a significant accumulation of lymphocytes $(22.1 \pm 3.5 \%$ of total BAL cells), in contrast to the number of lymphocytes found in the BAL of AdV-NULL-treated mice $(2.7 \pm 0.8 \%$ of total BAL cells). BAL cells were stained and analyzed with flow cytometry for CD3 and CCR6. Only a small fraction of T-lymphocytes stained positive for CCR6, whereas nearly a quarter of the splenocytes obtained from these mice were CCR6-positive (Figure 1A). These observations suggested that human CCL18 attracts 


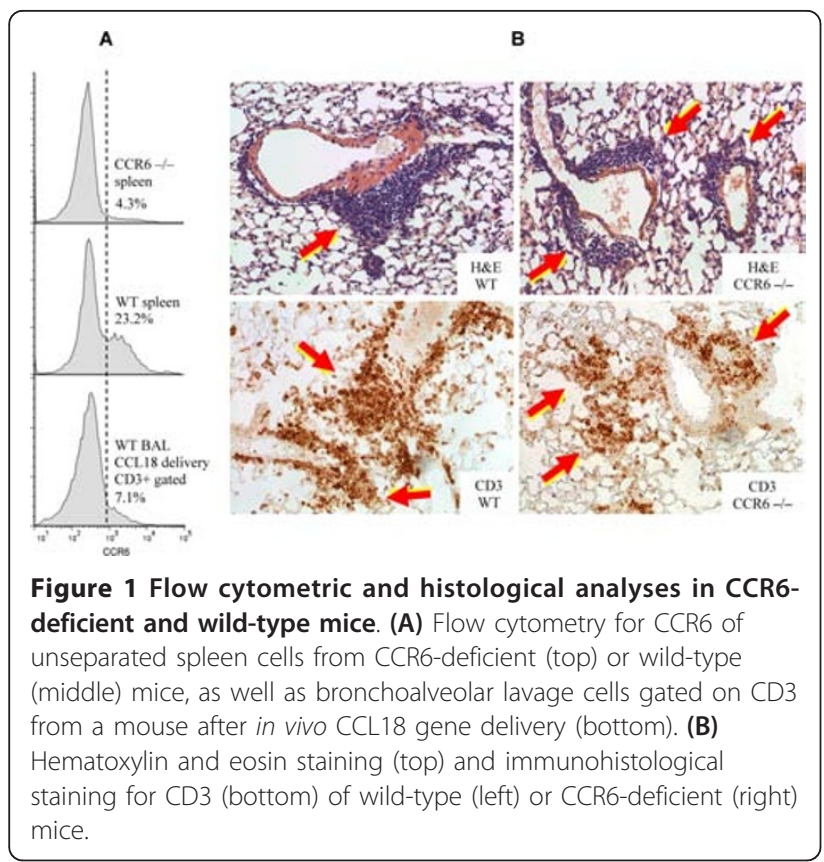

mostly CCR6-negative T-lymphocytes to mouse lungs, and that mouse CCR6 is not necessary for the functional response to human CCL18 in mice.

To further address this issue, we utilized homozygous CCR6-deficient (CCR6-/-) mice (The Jackson Laboratory). The CCR6-deficient status of these animals was confirmed by flow cytometry (Figure 1A). Three CCR6-/- and three wild-type mice were instilled with AdV-CCL18 on two different occasions, and a histologic analysis of the lung tissues was performed. In all cases, gene delivery of human CCL18 caused lymphocytic infiltration of mouse lungs, as previously described [3-5], although the infiltrates appeared smaller in the CCR6-/mice than in wild-type mice (Figure 1B). The smaller size of the infiltrates in the CCR6-/- mice may be explained by changes in the overall regulation of lymphocyte homeostasis in these animals [13]. Thus, lymphocytic infiltration of the lungs occurred in response to CCL18 in CCR6-deficient animals.

Based on these combined observations, it was concluded that mouse CCR6 is not necessary for CCL18induced changes in mice in vivo, and that CCR6 is not the main functional receptor for CCL18 in this model. These findings do not exclude the possibility that mice and humans utilize different receptors for CCL18, although this is unlikely considering the remarkable similarity of CCL18 effects on human and mouse lymphocytes $[3-5,9]$. Further research is necessary to identify CCL18 receptor(s), as the CCL18-dependent pathway is centrally involved in a variety of maladies, particularly $\mathrm{T}$ lymphocyte-mediated fibrotic pulmonary diseases [1].

\section{Abbreviations}

AdV: adenovirus; BAL: bronchoalveolar lavage; CCL18: CC chemokine ligand 18; CCR: CC chemokine receptor; CCR-/-: homozygous CCR6-deficient.

\section{Acknowledgements}

The authors thank Mrs Virginia Lockatell for her expert technical help. This work was supported by VA Merit Awards to IGL and to SPA, and by $\mathrm{NIH}$ NHLBI 1R21HL106196 to SPA.

\section{Author details}

${ }^{1}$ Department of Medicine, University of Maryland School of Medicine, Baltimore, MD 21201, USA. ${ }^{2}$ Baltimore VA Medical Center, Baltimore, MD 21201, USA

\section{Authors' contributions}

IGL participated in the experimental design, performed the experiments and participated in data interpretation. SPA conceived the study; participated in its design, coordination and data interpretation; performed statistical analyses; and wrote the manuscript. Both authors read and approved the final manuscript.

\section{Competing interests}

The authors declare that they have no competing interests.

Received: 10 January 2012 Accepted: 18 January 2012

Published: 18 January 2012

\section{References}

1. Luzina IG, Todd NW, lacono AT, Atamas SP: Roles of T lymphocytes in pulmonary fibrosis. J Leukoc Biol 2008, 83:237-244.

2. Luzina IG, Atamas SP, Wise R, Wigley FM, Xiao HQ, White B: Gene expression in bronchoalveolar lavage cells from scleroderma patients. Am J Respir Cell Mol Biol 2002, 26:549-557.

3. Luzina IG, Papadimitriou JC, Anderson R, Pochetuhen K, Atamas SP: Induction of prolonged infiltration of $\mathrm{T}$ lymphocytes and transient $\mathrm{T}$ lymphocyte-dependent collagen deposition in mouse lungs following adenoviral gene transfer of CCL18. Arthritis Rheum 2006, 54:2643-2455.

4. Pochetuhen K, Luzina IG, Lockatell V, Choi J, Todd NW, Atamas SP: Complex regulation of pulmonary inflammation and fibrosis by CCL18. Am J Pathol 2007, 171:428-437.

5. Luzina IG, Todd NW, Nacu N, Lockatell V, Choi J, Hummers LK, Atamas SP: Regulation of pulmonary inflammation and fibrosis through expression of integrins alphaVbeta3 and alphaVbeta5 on pulmonary T lymphocytes. Arthritis Rheum 2009, 60:1530-1539.

6. Hieshima K, Imai T, Baba M, Shoudai K, Ishizuka K, Nakagawa T, Tsuruta J, Takeya M, Sakaki Y, Takatsuki K, Miura R, Opdenakker G, Van Damme J, Yoshie O, Nomiyama H: A novel human CC chemokine PARC that is most homologous to macrophage-inflammatory protein-1 alpha/LD78 alpha and chemotactic for T lymphocytes, but not for monocytes. J Immunol 1997, 159:1140-1149.

7. Kodelja V, Müller C, Politz O, Hakij N, Orfanos CE, Goerdt S: Alternative macrophage activation-associated CC-chemokine-1, a novel structural homologue of macrophage inflammatory protein-1 alpha with a Th2associated expression pattern. J Immunol 1998, 160:1411-1418.

8. Tasaki Y, Fukuda S, lio M, Miura R, Imai T, Sugano S, Yoshie O, Hughes AL, Nomiyama $\mathrm{H}$ : Chemokine PARC gene (SCYA18) generated by fusion of two MIP-1alpha/LD78alpha-like genes. Genomics 1999, 55:353-357.

9. Guan P, Burghes AH, Cunningham A, Lira P, Brissette WH, Neote K, McColl SR: Genomic organization and biological characterization of the novel human CC chemokine DC-CK-1/PARC/MIP-4/SCYA18. Genomics 1999, 56:296-302.

10. Zissel G, Höhne K, Kilic A, Maier C, Goldmann T, Prasse A, Plönes T, Trepel M, Eibel H, Muller-Quernheim J: Identification of the CCL18 receptor - effects of CCL18 on human lung fibroblasts in pulmonary fibrosis are mediated via CCR6. Am J Respir Crit Care Med 2011, 183:A5574.

11. Fushimi T, Kojima A, Moore MA, Crystal RG: Macrophage inflammatory protein 3alpha transgene attracts dendritic cells to established murine tumors and suppresses tumor growth. J Clin Investig 2000, 105:1383-1393.

12. Chavan R, Marfatia KA, An IC, Garber DA, Feinberg MB: Expression of CCL20 and granulocyte-macrophage colony-stimulating factor, but not 
Flt3-L, from modified vaccinia virus ankara enhances antiviral cellular and humoral immune responses. J Virol 2006, 80:7676-7687.

13. Lügering A, Floer M, Westphal S, Maaser C, Spahn TW, Schmidt MA, Domschke W, Williams IR, Kucharzik T: Absence of CCR6 inhibits CD4+ regulatory T-cell development and M-cell formation inside Peyer's patches. Am J Pathol 2005, 166:1647-1654.

doi:10.1186/1755-1536-5-2

Cite this article as: Luzina and Atamas: CCR6 is not necessary for functional effects of human CCL18 in a mouse model. Fibrogenesis \& Tissue Repair 2012 5:2.

Submit your next manuscript to BioMed Central and take full advantage of:

- Convenient online submission

- Thorough peer review

- No space constraints or color figure charges

- Immediate publication on acceptance

- Inclusion in PubMed, CAS, Scopus and Google Scholar

- Research which is freely available for redistribution

Submit your manuscript at www.biomedcentral.com/submit
() Biomed Central 